\title{
HIDDEN INFORMATION IN PAINTINGS THAT MANIFESTS ITSELF IN THE NEAR INFRARED SPECTRUM
}

\section{SKRIVENA INFORMACIJA U SLIKARSTVU KOJA SE MANIFESTIRA U BLISKOM INFRACRVENOM SPEKTRU}

\author{
Jana Žiljak Gršić1, Lidija Tepeš Golubić1, Denis Jurečić2, Maja Matas ${ }^{2}$ \\ Zagreb University of Applied Sciences, Zagreb, Croatia ${ }^{1}$; Faculty of Graphic Arts, University of Zagreb, Zagreb, Croatia ${ }^{2}$ \\ Tehničko veleučilište u Zagrebu, Zagreb, Hrvatska ${ }^{1}$; Grafički fakultet, Sveučilište u Zagrebu, Zagreb, Hrvatska
}

\section{Abstract}

For each pigment and dye, we associate information about their absorption of light in the near infrared spectrum (NIR) at $1000 \mathrm{~nm}$. Generally, pigments red, yellow, cyan blue, orange, white and "drap" (sandy brown) do not absorb NIR light. The NIR camera does not distinguish, recognize or "see" them, so the NIR photo is white. Such colors are marked with the letter "V" (visual, VIS). The area of green pigments (in our language, "zeleno" = green) is very different considering the absorption properties of NIR radiation. Some green pigments strongly absorb NIR radiation, while some green pigments absorb very little. That is why we have introduced the acronym $\mathrm{Z}$ as numerical information on the absorption of NIR light for all colorants, with a range from zero to ten. Painters are trained to mix colors with respect to their $Z$ values. Dual images are produced. The NIR camera separates the drawing, the image, depending on the amount of $\mathrm{Z}$ color. The painter succeeds in arranging the colors so discreetly that two images are taken in the same place, one of which is seen by the naked eye, while the other requires an NIR camera to be seen. The idea of a VIS / NIR painting is accepted with the realization that there are many video surveillance (NIR) cameras around us: on the streets, in restaurants, in banks, in public entrances and entrances to private houses in general. The NIR design is used on documents, diplomas and banknotes as a general security method in graphic technology.

\section{Sažetak}

Svakom pigmentu i bojilu dodjeljujemo informaciju o njihovoj apsorpciji svijetlosti u bliskom infracrvenom spektru (NIR) na $1000 \mathrm{~nm}$. Općenito, crveni pigment, žuti, cijan plavi, naranđasti, bijeli i drap (svjetlo smeđi) ne apsorbiraju NIR svjetlost. NIR kamera ih ne razlikuje, ne prepoznaje ili "ne vidi", pa je za njih NIR fotografija bijela. Te boje su označene sa slovom V (vidljive, VIS). Prostor zelenih pigmenata (na našem jeziku, "zeleno" = Z) je veoma različit što se tiče apsorpcije NIR radijacije. Neki zeleni pigmenti jako apsorbiraju NIR radijaciju, dok neki zeleni pigmenti apsorbiraju vrlo malo. To je razlog zašto smo uveli akronim $\mathrm{Z}$ kao numerička informacija za apsorpciju NIR svjetlosti za sva bojila; u rasponu od nule do deset. Slikare smo uvježbali da miješaju bojila s respektom prema njihovoj $Z$ vrijednosti: Proizvode se dvostruke slike. NIR kamera razdvaja crteže, slike, ovisno o količini $\mathrm{Z}$ boja. Slikar uspijeva uređivati boje tako diskretno da su dvije slike na istom mjestu; jedna koja je vidljiva golim okom, dok je za drugu potrebna NIR kamera da bi ju vidjeli.

Ideja o VIS / NIR slikarstvu je prihvaćena i realizirana budući da u našoj okolici postoje mnoge nadzorne (NIR) kamere: na ulici, u restoranima, u bankama, na društvenim ulazima te općenito na ulazima u privatne kuće. NIR dizajn se koristi na dokumentima, diplomama i novčanicama kao opća sigurnosna metoda u grafičkoj tehnologiji. 


\section{INTRODUCTION}

This article deals with the innovation in the technology of art. Apart from the aforementioned, these paintings are capable of presenting two different pieces of information to the recipient. By applying the VIS (visual spectrum) and NIR (near infrared spectrum), the artist hides a part of her artwork, message and information that she intends to use to surprise the person watching $/ \mathbf{1} /$. The result of such a way of

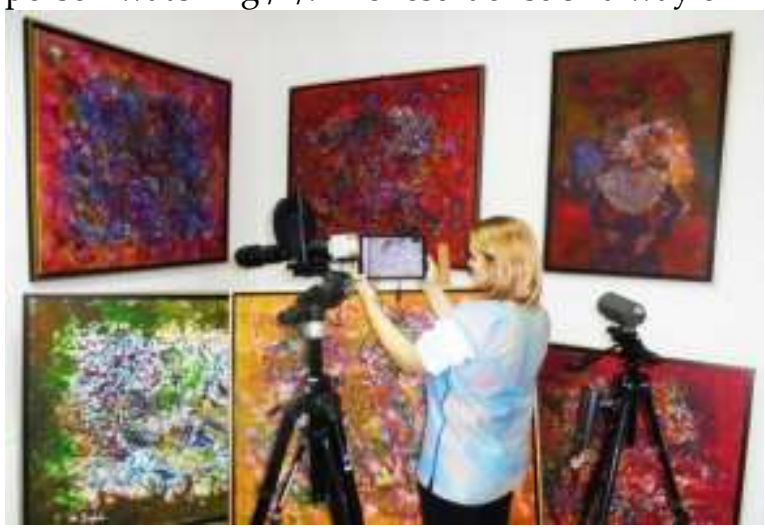

using this innovative method of making artwork is new paintings that have found their place in contemporary art galleries $/ \mathbf{2} /$. It is suggested to extend the measurement of parameters that describe colors and colorants both in the VIS and NIR spectrum. It is a new tool for studying images of old as well as modern masters. Painting is also improved in the areas of individualization, authorship attribution and the safety of the work of art.

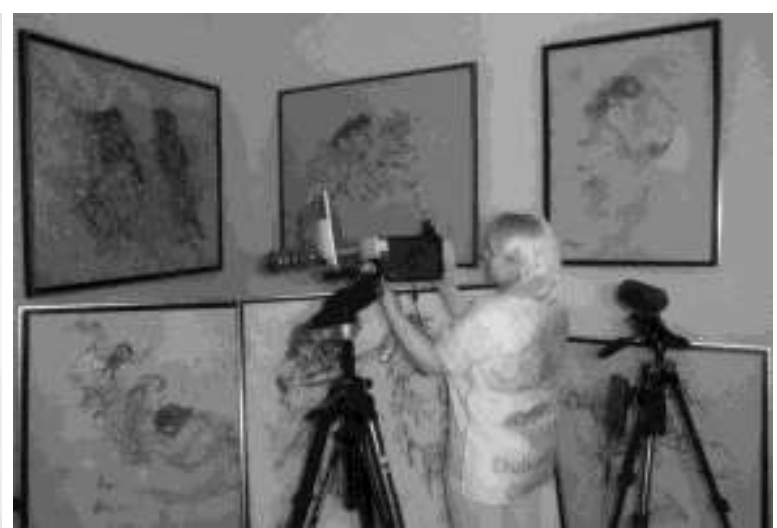

Image 1: Dual information of paintings; visual and near infrared reflectography

There are many examples where old masters painted a new image over the old image /3/. NIR cameras reveal those parts of paintings that were painted with paint colors which strongly absorb NIR radiation /4/. The painters did not know that something would be revealed with the NIR detection method.

Many artworks of old masters were analyzed in the last century by spectroscopy and by the method of "infrared reflectography" /5/. New information was sought in the artwork and a new look at the creation of visual arts. Different layers of dyes were detected - one colorant over another colorant. The thickness of the paint layer was evaluated. Some smaller portions of pre-painted images (picture over the picture) have been found. This research did not create the incentive for new artists to deliberately create dual images that carry hidden information, such as stacking two colors, one in touch with the other (not one over the other). Two dyes of the same color tone but with different responses in the near infrared spectrum. With the advent of digital infrared cameras $/ \mathbf{6}$ / that have a digital display, the artist can control the dual image in real time. The artist at the same time "sees", he is aware of his dual creations, and controls the two pictures. Infrared art is an innovation implying the deliberate creation of images in the $\mathrm{V}$ and $\mathrm{Z}$ spectra.

The method uses twin dyes - two dyes made from different recipes that have the same color tone, but which respond differently in the NIR spectrum $/ 7 /$. The principle of hand mixing twin dye recipes was shown for set color tones used in documents /8/. Pairs of twin dyes were mixed with offset process colorants Cyan, Magenta, Yellow and Carbon Black and applied by hand on paper /9/. In print, dual reproductions were made because each color tone is realized in at least two formations and two different appearances in the VIS and NIR spectra /10/.

In art, academically trained painters Nada Žiljak (Image 4) and Diana Nazor (Image 3) have developed different methods of creating twin colorants for use in painting. Innovative visual artistry of creating artworks that are viewed in the VIS and NIR spectrum with 
ZRGB cameras was established /11/. The painters control the visual spectrum by consulting the absorption of radiation in the near infrared area. They achieved the richness of color (VIS) with a single tone by drawing on their experience with the implementation in the NIR spectrum $/ \mathbf{1 2} /$. Since colorants have significant differences in NIR spectrum, they have developed a new dual painting. Two levels in one artwork create extraordinary possibilities for expression and information placement. It is from there that expanded meanings and approaches to concepts are being introduced in a new way into fine art: concealment, intimate painting, invisible images, hidden information and security design $/ \mathbf{1 3} /$.

Intimate and hidden invisible artworks were created with the dual state infrared dyes by painters Nada and Dijana /14/. Multi-layered painting uses the effects of overlapping and transparency. The extreme case is the covering of the dried "Z-dark" color (permanent green, such as Z drawing) with a light yellow color for the VIS view. The effect of transparency is achieved; the first drawn Z-dark NIR drawing is revealed in the place of the yellow area (VIS). Infrared painting has developed a new tool for studying images of both old and modern masters and brought innovation in the creation of new artworks. The result is a new painting method that has found its place in contemporary art galleries and museums /2/. Painting is also improved in the areas of individualization, authorship attribution and the safety of the work of art $/ 1 /$.

\section{NEW INFORMATION ON PIGMENT PROPERTIES IN THE NIR SPECTRUM}

The absorption properties of the light in the NIR spectrum are being added to the colorants for fine art. To each colorant - oil, acrylic, tempera, ceramic color or watercolor - we are adding the numerical value of absorption of light at 1000 nm.

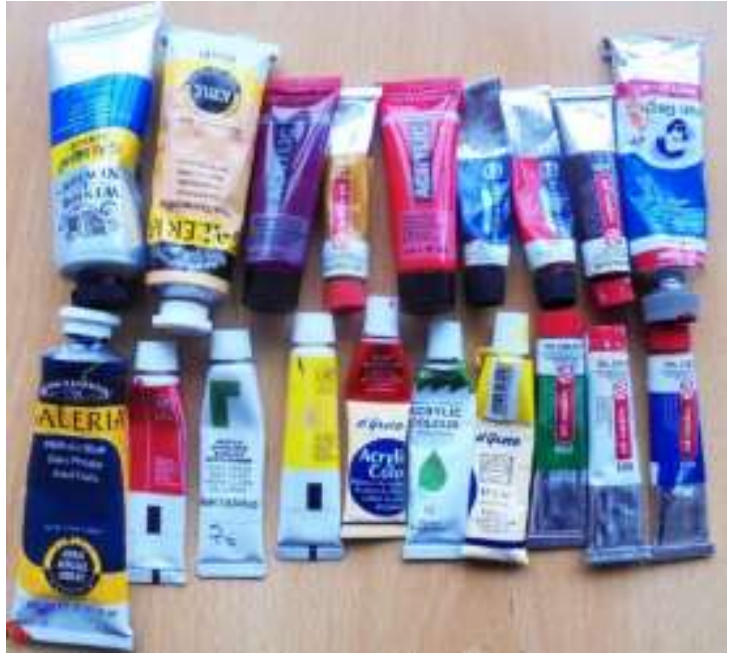

Image 2 a: Colorants for fine art

In this article, the results of the measurement of the absorption of color for oil colorants (oil) and acrylic (ac) dye in two spectra, VIS and NIR, are published. The colorants are described with the VIS values of RGB and $L^{*} a^{*} b$, and the NIR values "absorption" and "Z". Value $Z$ is introduced (range from 0 to 10 ), which is joined to colorants and pigments for artistic painting as the value of light absorption at $1000 \mathrm{~nm}$.

Each colorant has a specific value of $Z$. There is no correlation between NIR1000, the marked value $\mathrm{Z}$ and the brightness values " $\mathrm{L}$ " of individual colorants (Table 1 ).

In this article, the "V colorant" is defined as the colorant that does not absorb (or absorbs only minimally) the radiation from the NIR area. The "Z colorant" is the colorant that is visible to the naked human eye, but this colorant also absorbs NIR radiation well.

Different matter or different pigments absorb NIR light differently. This does not depend on the thickness of the dye layer. In Image 2 b, some inks have different thickness on paper. A red dye, for example $(2,5,15,17)$, does not absorb NIR light, regardless of the thickness of the dye. 


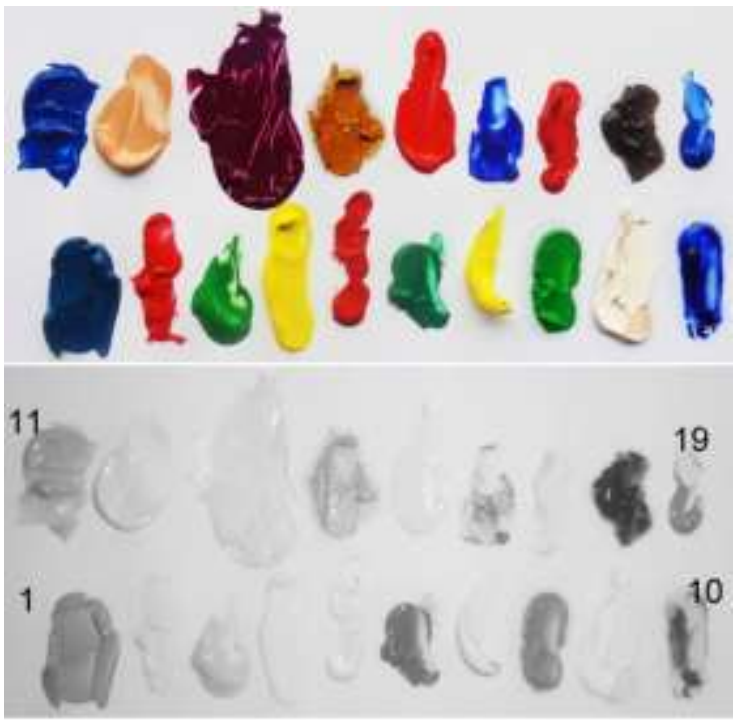

Image $2 \mathrm{~b}$ : Nineteen dyes in VIS and NIR camera with a custom filter of $1000 \mathrm{~nm}$

Table 1. 19 Colors for artistic painting

\begin{tabular}{|c|c|c|c|c|c|}
\hline & & & $R, G, B$ & $L^{*} a^{*} b$ & Z \\
\hline 1 ac & Phthalo Blue & Winsor \& Newton & $11,45,90$ & $18,3,-31$ & 4.3 \\
\hline $2 \mathrm{ac}$ & Brilliant red & Reeves & $219,14,8$ & $45,68,58$ & 1.5 \\
\hline $3 \mathrm{ac}$ & Light green & Reeves & $8,141,34$ & $51,-49,44$ & 2.1 \\
\hline $4 \mathrm{ac}$ & Lemon yellow & Reeves & $236,211,22$ & $85,-3,81$ & 1.3 \\
\hline 5 ac & Carmine red & el Greco & $205,34,27$ & $45,64,50$ & 1.3 \\
\hline $6 \mathrm{ac}$ & Sap green & ASTM D4236 & $22,107,66$ & $40,-33,16$ & 4.8 \\
\hline 7 ac & Yellow lemon & el Greco & $252,243,18$ & $94,-11,90$ & 1.2 \\
\hline 8 oil & Permanent green & Talens & $2,133,17$ & $48,-48,47$ & 4.2 \\
\hline 9 oil & Titanium white & Talens & $234,231,216$ & $92,-1,8$ & 1.4 \\
\hline 10 oil & Ultramarine & Talens & $1,12,180$ & $20,49,-84$ & 6.5 \\
\hline $11 \mathrm{ac}$ & Process cyan & Winsor \& Newton & $5,41,161$ & $23,30,-68$ & 3.8 \\
\hline $12 \mathrm{ac}$ & Terracotta hell & Winsoe \& Newton & $226,153,76$ & $70,23,51$ & 1.8 \\
\hline $13 \mathrm{ac}$ & Perm. Red violet & Amsterdam & $60,76,65$ & $10,24,7$ & 1.5 \\
\hline 14 oil & Yellow ochre & Talens & $190,81,14$ & $49,43,55$ & 3.2 \\
\hline $15 \mathrm{ac}$ & Pyrrole red & Amsterdam & $216,19,13$ & $47,70,58$ & 1.2 \\
\hline $16 \mathrm{ac}$ & Ultramarine & Talens & $19,22,155$ & $19,40,-72$ & 2.5 \\
\hline $17 \mathrm{ac}$ & Naphthol red & ASTM D 4236 & $203,28,25$ & $44,65,50$ & 1.2 \\
\hline 18 oil & Burnt umber & Talens & $59,45,42$ & $20,6,5$ & 7.8 \\
\hline $19 \mathrm{ac}$ & Cobalt blue & van Gogh & $15,33,157$ & $21,34,-69$ & 4.3 \\
\hline
\end{tabular}

Measurements of $Z$ values are applied to many dyes used by painters. Table 1 contains the numerical data for dyes of different manufacturers - 5 oils and 14 acrylics. Prior to measuring the
RGB (Red, Green, Blue) values, the dyes were homogenized and then freely applied to the paper. Photos with ZRGB cameras show the same contours in the visual and NIR spectrum, as 
well as the information on the thickness of the color layers. The $\mathrm{Z}$ value (Table 1, column 6) is used by painters to plan a hidden image that will be viewed with the NIR camera. Color planning involves various color mixing procedures, different color thicknesses and dye transparency properties in both spectra - the visual and NIR.

The value of "L" (Table 1, column 5) is the information about the brightness of the color. It determines its gray state in the visual spectrum; in other words, it makes the image look black and white. Since the NIR image manifests itself to our eyes as a gray $\mathrm{Z}$ image (with a ZRGB camera), here we emphasize that there is no correlation between the $\mathrm{L}$ and $\mathrm{Z}$ values (Tab. 1, column 6).

Our research has been expanded to create new colors with the aim of improving infrared painting. By mixing the dyes, a large difference between $\mathrm{L}$ and $\mathrm{Z}$ is obtained. The painters offered the method of creating two black "S" and "K" (J97) dyes that differ extremely in the absorption of NIR light. These two black dyes are the beginning of a firm control in deciding on and choosing colors in infrared painting. The painter uses twin dyes that are equal in their visual appearance and different in the NIR spectrum. For example, that light brown color has a strong (dark) absorption of $Z$ values. That dark (almost black) brown color has a very small $\mathrm{Z}$ value.

The painter thinks of the $Z$ value of a particular colorant and what colorant will be used for a dual image painting. Is it going to be the $\mathrm{V}$ or $\mathrm{Z}$ colorant? The painter consults the information on the "NIR visibility" of a set of colors bought in a fine art shop. The value of $\mathrm{Z}$ is determined, measured with a forensic instrument [8], and this value is the absorption power (information) in the infrared spectrum of the wavelength at
$1000 \mathrm{~nm}$. The painter uses the NIR camera during the creation of a dual image. The same camera is also set up at the art exhibition for observing hidden drawings (Image 1).

Followers of infrared painting have developed a method of mixing colorants where colorant transparency properties and multilayered painting for various colorants are applied to paper, canvas, leather, metal and glass. For each material, a color combination for the associated painting technology was discovered. Measurements of the $\mathrm{Z}$ values and the absorption of radiation with a blockage at $1000 \mathrm{~nm}$ are performed before the act of painting.

Today, intentional duality is created with the NIR process of painting to achieve two things: the individualization of the artwork and the creation of a hidden drawing. Success depends on the manipulation of colorant properties in the area of light absorption, but with selective observation in the VIS and NIR area.

\section{ARTWORK IN LIGHT BLOCKINGS}

Until the NIR painting research, painters had never observed or looked at colorants for fine art in the NIR spectrum with different light blockages. They are aware that every color tone can be mixed in many ways with components that respond differently in the NIR spectrum. Same colors with different $Z$ values initiated the idea of creating artistic images with a targeted response in the NIR spectrum.

Two images in an artwork, the NIR and VIS image, were photographed with a camera that has twenty filters showing a picture ranging from $245 \mathrm{~nm}$ to $1000 \mathrm{~nm}$. Such images fall into an extremely forensic area. For this purpose, photos are merged into a continuous video presentation with the ability to stop at the desired wavelength. 

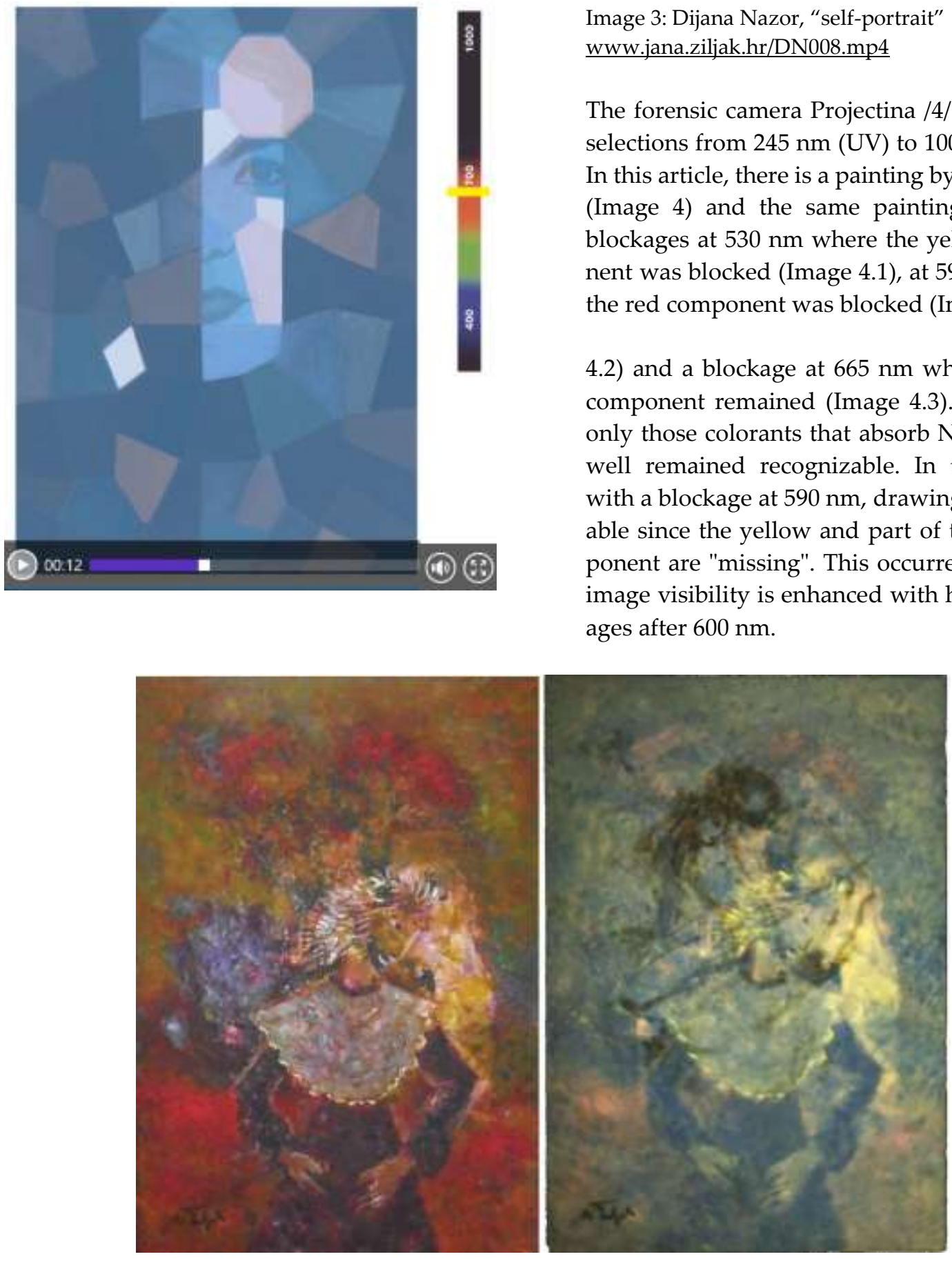

Image 4.1. 4.2: Nada Žiljak, "Zagrljaj”, infrared fine art, visual and blockage red Animation at: www.nada.ziljak.hr/n134.mp4

Image 3: Dijana Nazor, "self-portrait"

$\underline{\text { www.jana.ziljak.hr/DN008.mp4 }}$ the red component was blocked (Image ages after $600 \mathrm{~nm}$.

The forensic camera Projectina /4/ has 24 filter selections from $245 \mathrm{~nm}$ (UV) to $1000 \mathrm{~nm}$ (NIR). In this article, there is a painting by Nada Žiljak (Image 4) and the same painting with light blockages at $530 \mathrm{~nm}$ where the yellow component was blocked (Image 4.1), at $590 \mathrm{~nm}$ where

4.2) and a blockage at $665 \mathrm{~nm}$ where the blue component remained (Image 4.3). At $850 \mathrm{~nm}$, only those colorants that absorb NIR radiation well remained recognizable. In the painting with a blockage at $590 \mathrm{~nm}$, drawing $\mathrm{Z}$ is noticeable since the yellow and part of the red component are "missing". This occurrence of the $\mathrm{Z}$ image visibility is enhanced with higher block- 

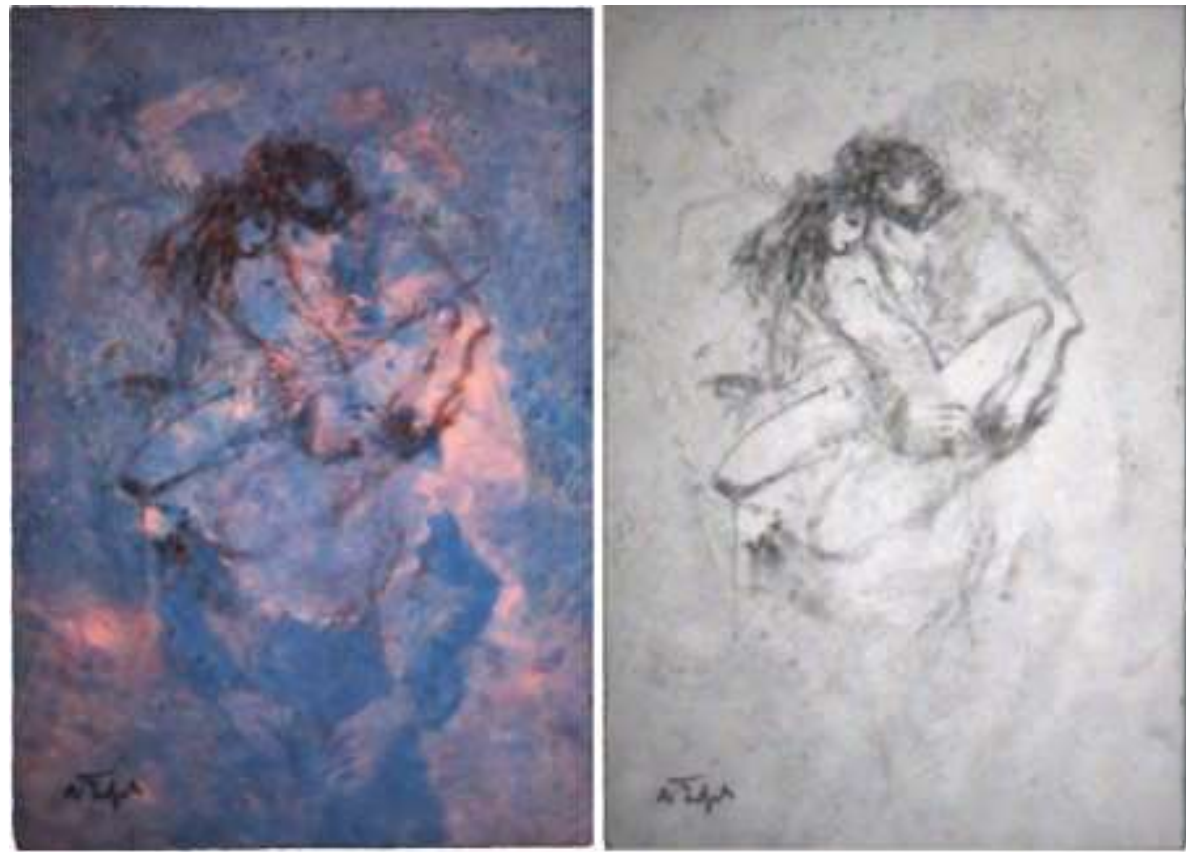

Image 4.3, 4.4: in blockage green and $\mathrm{Z}$ photo at $850 \mathrm{~nm}$

The "light block" technique of $245 \mathrm{~nm}$ to 1000 $\mathrm{nm} / 4$ / brings new information about the work of art. The same image was shot in 24 blockages with the intention of creating the animation of a continuous transition from the VIS to the NIR image state. This video recording is archived on the web site: www.nada.ziljak.hr/n134.mp4 (animation of the transition from visual to near infrared). Other paintings by Nada Žiljak are documented as an animation, and the intent is multifaceted. This is a new approach to artistic images intended for many areas of color research in artworks: the area of the safety of the artwork, the exploration of coloring methods, learning about spectroscopy, dual painting, the innovation of the development of new colorants and the new approach to learning about light. Additionally, an image expanded with hidden NIR image information is highly protected. It is almost impossible to copy and paint on canvas an artwork that would have a dual image.

The painter of the future thinks about which colorant will be used in the moment of inspiration for concealing the idea of his artistic expression in order for the $\mathrm{Z}$ image to appear on canvas independently from the $\mathrm{V}$ image. Or, would it depend on the $\mathrm{V}$ image? Answers to these questions are creating a new form of fine art. The $\mathrm{Z}$ image is also viewed with the forensic camera /4/ that translates the $Z$ recording and makes it visible. This camera not only records the $\mathrm{V}$ image, but also extracts the $\mathrm{Z}$ image for different sunlight blockages.

\section{CONCLUSION}

In this paper we presented an innovative way of showing hidden images and information in a way invisible to the human eye. Only by using the NIR camera /6/ can the recipient enjoy dual colorant properties that are used to create two separate artworks.

The painter has a new tool for painting in the "dark", such as in the "night shot" process of creating his/her own mysterious image or multilayered design. The result is a double image, two images that differ in content and in artistic rating.

In this way considerable improvements have been introduced in the area of security, originality, publications of old masters and restoration. Artistic expression through manners in which oil colors are used is a new endeavor in fine art: hidden image, invisible information. Dual colorant properties are used to create separate graphics that will only be seen with the NIR camera.

The same color tone can be mixed in many ways in other technologies in the vast area of fine art. 
The shades of the colorants' sameness and difference are revealed with the ZRGB /11/ camera and with the spectral graphs of light absorption in the VIS and NIR area.

Expansion of colorant analysis into the NIR spectrum will initiate new interpretations of fine art paintings. At the same time a new NIR painting technique is being developed. The IR painting process initiates systematic colorant classification according to their response and differences in the VIS and NIR spectrum. The extended view of the painting becomes an integral part of the painting process and expression.

\section{Notes}

/1/ Žiljak, V., Pap, K., Žiljak-Stanimirović I., ŽiljakVujić, J. (2009). Information Control in the Infrared Area of Spectrum, Informatologia. vol. 42, no.1. pp, 1-9.

/2/ Infrared ART, Muzej Mimara, Zagreb (2008). "INFRARED PAINTING Nada Žiljak", http://www.nada.ziljak.hr/VIS-NIRspektar.pdf and Galerija Sv. Ivan Zelina, http://www.galleryhr.com/NADAZILJAK.htm

/3/ Nazor D. (2014), “Pronalaženje skrivene informacije $u$ infracrvenom spektru na slikama u Samostanu karmelićana u Remetama i u privatnoj zbirci u Zagrebu“, POLYTECHNIC AND DESIGN, vol. 2, no. 2, p:153-162. DOI: 10.19279/TVZ.PD.2014-2-2-022.

/4/ Projectina Docucenter with SP-2000 color spectroscopy module \& PAG B50 custom designed with 24 barrier filters, http://forensictechnology.com/projectina/

http://www.telectronics.biz/assets/mainmenu/104/editor/PDF_leaflet_Docucenter_4500.pdf

https://web.archive.org/web/20110830234641/

http://www.projectina.ch/cre8.upload/pdfs/UCM\%20LED\%20PIA7000\%202011-e.pdf

/5/ Vokić, D., Zlodi, G. (2012). “Dokumentiranje baštine prirodoznanstvenim metodama", Godišnjak zaštite spomenika kulture Hrvatske, Sveučilište u Dubrovniku / Filozofski fakultet Sveučilišta u Zagrebu, Odsjek za informacijske i komunikacijske znanosti, p 181-208, UDK: 7.025.3/.4:001.8

/6/ Rajković, I., Žiljak, V. (2016). “Usage of ZRGB video camera as a detection and protection systemand development of invisible infrared design", POLYTECHNIC \& DESIGN; vol. 4, no. 1, pp: 54 - 59; ISSN 2459-6302, ISSN 1849-1995, DOI: 10.19279/TVZ.PD.2016-4-1-07

/7/ Agić, D., Agić A., Bernašek, A. (2013). “Blizanci bojila za proširenje INFRA informacijske tehnologije" POLYTECHNIC AND DESIGN vol. 1, no 1 , pp 27-32

/8/ Matas, M. (2017). “Twin dyes for security printing in infrared mapping", Sveučilište u Zagrebu, Grafički fakultet doktorska disertacija, pp: $1-138$

19/ Žiljak-Gršić, J. (2017). “Near infrared spectroscopy in print technology", POLYTECHNIC \& DESIGN, vol. 5, no. pp:32-36, DOI: 10.19279/TVZ.PD.2017-5-1-05 ， DOI: 10.19279/TVZ.PD.2017-5-1-05-en

/10/ Pogarčić I., Agić, A., Matas, M. (2016). “Evaluation of the colorant twins for the neutral grey spectra in infrared graphic procedure" Technical Gazette, vol. 23, no. 6, pp:1659-1664, ISSN 1330-3651, ISSN 1848-6339, DOI: 10.17559/TV20150303132036, Hrčak ID: 169526

/11/ Žiljak, V., Pap, K., Žiljak-Stanimirovic, I. (2011) "Development of a prototype for ZRGB infraredesign device", Technical Gazette, vol. 18, no. 2; pp:153-159

/12/ Žiljak-Vujić, J., Nazor, D., Tepeš-Golubić L., (2015). “Expanded communication of paintings consideration and conceptualization of the works of art in the infra-red area, of modern and contemporary artists", SOCIETY \& TECHNOLOGY, DIT, Juraj Plenković, pp.212-218.

/13/ Gršić, J., Tepeš-Golubić, L., Rajković, I. (2018). "Scenography and costume design in visual and infrared spectrum", 5TH International multidisciplinary scientific conference on social science \& arts // SGEM 2018, Conference proceedings pp: 511 -516, vol.5, no. 6.1/ Performing and visual arts, ISBN 978-619-7408-34-8 ISSN 2367-5659 DOI: 10.5593/sgemsocial2018H/61

/14/ Jurečić, D., Žiljak, V., Tepeš-Golubić, L., Gršić, J. (2017). "Spectroscopy of colorants for fine art in visual and near infrared spectrum", "2nd International conference on applied physics, system science and computers" 